\title{
Contra a cultura do corta \& cola
}

A revolução na tecnologia da informação, especialmente o advento da Internet, influenciou de forma significativa comportamentos e processos na sociedade. Os termos cultura "read only" (RO - somente leitura) e "read/write" (RW - leitura e escrita) foram cunhados por Lawrence Lessig (Remix: Making Art and Commerce Thrive in the Hybrid Economy. Penguin Books; 2009) para caracterizar as profundas mudanças que ocorreram na forma de produção e consumo de produtos culturais. O hábito de reproduzir passivamente músicas e vídeos criados por terceiros (a cultura RO), vem sendo substituído por uma postura mais ativa por parte de consumidores que, empregando softwares de edição de uso doméstico, passaram a produzir obras derivativas ("mashups"), editando, combinando e transformando conteúdos armazenados na internet para a criação de novos produtos (a cultura RW). Uma das marcas dessa nova forma de produzir e consumir cultura é o seu caráter colaborativo.

O caráter colaborativo é também uma marca importante da atividade científica. A célebre citação atribuída a Isaac Newton "se eu vi mais longe, foi por estar de pé sobre ombros de gigantes" traduz a importância que a produção coletiva do conhecimento tem para o avanço da ciência. É no formato RW que se consome e produz ciência. As novas tecnologias de informação facilitaram o armazenamento de conteúdos e a conectividade entre pesquisadores, criando um ambiente favorável ao desenvolvimento da cultura RW. Esse avanço, entretanto, também tem facilitado o plágio e a publicação redundante ("auto-plágio"), fazendo crescer no meio acadêmico uma indesejável cultura do Cut \& Paste (corta \& cola).

Um estudo recente evidenciou um aumento da retratação de artigos motivada por plágio em periódicos das áreas biomédica e das ciências da vida (Fang FC et al. Misconduct accounts for the majority of retracted scientific publications. Proc Natl Acad Sci U S A 2012; 109:17028-33). A despeito do número de denúncias de plágio ou publicação redundante em CSP ainda ser em termos absolutos muito pequeno, também percebemos uma tendência de crescimento, o que nos motivou a rever nossa política editorial. Além de buscar uma maior adequação às diretrizes produzidas pelo COPE (Committee on Publication Ethics), incluindo, entre outras iniciativas, o processo, ora em curso, de nos tornarmos membros desta organização, estamos em fase de implantação da verificação automática de plágio em todos os artigos submetidos a CSP. Por vezes a detecção (e usamos aqui propositalmente esta palavra, pensando mesmo em trabalho de detetive) por software não é suficiente. Mudanças de algumas palavras, por exemplo, ou a junção de trechos copiados de mais de uma fonte, dependem do olhar humano, capaz de identificar semelhanças mais vagas, que são então trazidas à atenção das editoras.

Uma vez estabelecido que houve cópia, seguiremos os fluxogramas do COPE, que fornecem orientações gerais para publicação redundante (http://publicationethics.org/files/ u7140/redundant\%20publication\%20A.pdf) e plágio (http://publicationethics.org/files/ u7140/plagiarism\%20A.pdf).

Essas mudanças buscam reforçar o nosso compromisso em garantir a integridade dos conteúdos publicados em CSP, que, dessa forma, continuará cumprindo a sua missão de ser um veículo para a disseminação de ideias relevantes, originais e criativas.

\author{
Marilia Sá Carvalho \\ Claudia Travassos \\ Cláudia Medina Coeli \\ Editoras
}

